\title{
The representation of business interests during the COVID-19 pandemic in Spain
}

\author{
La representación de los intereses empresariales \\ durante la pandemia de la COVID-19 en España
}

\author{
LAURA CHAQUÉS-BONAFONT \\ University of Barcelona and IBEI
}

IVÁN MEDINA

University of Valencia

\section{Cómo citar/Citation}

Chaqués-Bonafont, L. y Medina, I. (2021). The representation of business interests during the COVID-19 pandemic in Spain. Revista Española de Ciencia Política, 57, 21-44. Doi: https://doi.org/10.21308/recp.57.01

\begin{abstract}
This article explains the representation of business interest during the COVID-19 pandemic. The article describes how business interests get into the policy process across policy areas and political venues. Following previous studies (Dür and Mateo, 2016), the article argues the COVID-19 pandemic did not alter business groups' position in the policymaking process. Business groups occupy a predominant role in the discussion of policy proposals vis-à-vis other types of groups during the COVID-19 in the governmental arena, and this is especially the case for economy related policies and agriculture affairs. In contrast, business groups occupy a secondary role in the parliamentary arena, especially for non-economic issues. The article also explains which business associations represent business interest during the COVID-19 pandemic. The empirical strategy relies on two datasets developed by the Quality of Democracy Research Group (www.q-dem.com) containing information about interest groups' mobilization in the Spanish Congress of Deputies and the Spanish government from March 2020 to March 2021.
\end{abstract}

Keywords: business associations, COVID-19, interest groups, parliamentary lobbying, government.

\section{Resumen}

Este artículo explica la representación de intereses empresariales durante la pandemia de COVID-19. El artículo describe cómo las organizaciones empresariales participan en el proceso de elaboración de políticas públicas en diferentes áreas temáticas y espacios políticos. Siguiendo 
estudios previos (Dür y Mateo, 2016), el artículo sostiene que la pandemia COVID-19 no ha alterado la posición de los grupos empresariales en el proceso de formulación de políticas. Los grupos empresariales ocupan un papel predominante en la discusión de propuestas de políticas frente a otros tipos de grupos de interés durante la COVID-19 en la arena gubernamental, especialmente en el caso de las políticas relacionadas con la economía y los asuntos agrícolas. Por el contrario, los grupos empresariales ocupan un papel secundario en el Parlamento, especialmente en la discusión de cuestiones no económicas. El artículo también explica qué asociaciones comerciales representan intereses empresariales durante la pandemia. La estrategia empírica se basa en dos bases de datos desarrolladas por el grupo de investigación Calidad de la Democracia (www.q-dem.com) sobre la movilización de grupos de interés en el Congreso de los Diputados y el Gobierno espańol de marzo de 2020 a marzo de 2021.

Palabras clave: organizaciones empresariales, COVID-19, grupos de interés, Parlamento, Gobierno.

\section{INTRODUCTION}

Governmental responses to the coronavirus outbreak require the collaboration of interest groups. The COVID-19 pandemic has forced governments to adopt policy decisions like social distancing, school closings, teleworking, and expedientes de regulación temporal de empleo (ERTEs), which have high economic, political, and social costs, especially for the most vulnerable groups. In a context of great uncertainty, interest groups contribute to elaborate policy responses by preparing indicators, reports, and in-depth studies on specific problems. They also simplify the political debate by channeling the different views and ways of understanding policy responses to the public authorities. On some occasions, they also reduce the potential conflicts derived from the implementation of conflictual policy decisions. The problem is that interest groups' capacity to access the policy process is far from equal, and policymakers rarely consider the plurality of interests when discussing policy proposals and legislative initiatives dealing with the COVID-19 pandemic (Gilens and Page, 2014; Schattchneider, 1960).

This article explains the representation of interests during the COVID-19 pandemic, focusing on business groups. In particular, it explains the conditions under which business interests get into the policy process across policy areas and political venues. Do business groups occupy a predominant position in the discussion of policy proposals vis-à-vis other types of groups during the COVID-19 pandemic, and if so, is this dominant position equally important across policy areas? Existing research (Baumgartner et al., 2009; Schneider, 2006; Dür et al., 2019) shows that business groups occupy a predominant position in the policy process. Inequality stems from business capacity to create highly professionalized organizations. Moreover, business groups tend to monopolize the representation of business interests in the governmental area in which they maintain intense and highly stable interaction with members 
of government across time (Salisbury, 1969; Rhodes, 2006: 427). The institutionalization of business access to the policy process generates many opportunities for businesses to air their voices and inform policymakers about their views and ways of thinking about policy problems at the expense of the practical exclusion of other interest groups.

Existing research (Baumgartner et al., 2009, Fraussen et al., 2015) also argues that the privileged position of business groups in the policy process vis-à-vis other groups, like citizens and cause-oriented groups, is not homogenous and varies across policy areas and political scenarios. Dür and Mateo argue that business associations' ability to supply technical information before and during policy implementation provides them with access to executive institutions and regulatory agencies that have a great demand for these types of resources (2013: 153). In the same line, authors like Bouwen (2002) or Coen and Richardson (2009) argue that members of Parliament (MPs) interact with a wider variety of interest groups to get technical and legal expertise and political information. Other authors like Binderkrantz et al. (2015) or Baumgartner et al. (2009) argue that access opportunities for social groups grow as political arenas multiply. However, the privileged position of a few interest groups is never overthrown.

Following previous research, this article demonstrates that members of Parliament rely less on business groups to get technical and political information than on members of government, with significant differences across policy areas. The participation by business groups is marginal in the fields of rights, crime, and defense at both political arenas. Moreover, the article argues that the Confederación Española de Organizaciones Empresariales (CEOE) and its member associations share the representation of business interests with other relevant business associations, with significant variations across policy areas and political venues. The CEOE represents business interests with more intensity at the governmental arena than in Parliament, and its voice is mainly heard in economic policies other than agriculture. The Asociación Agraria de Jóvenes Agricultores (ASAJA) - member of the CEOE - does not monopolize the representation of interests in the agricultural sector. On the contrary, the interests of cattle ranchers, fishers, and farmers are scattered across different business associations, with a solid capacity to get access to policymaking across venues. Results also inform that the CEOE represented business interests regarding the Plan de Recuperación, Transformación y Resiliencia ${ }^{1}$, but it did not expand its scope of business representation to other policy areas.

In sum, the article concludes that the access by interest groups to policymakers across venues during the COVID-19 pandemic has followed a strategy similar to the one during regular times. The CEOE's involvement in social dialogue and collective bargaining remains indisputable, and business groups maintain a predominant position in the governmental arena with significant differences across venues. The article is

1. See: https://www.lamoncloa.gob.es/temas/fondos-recuperacion/Paginas/plan-de-recuperacion. aspx. 
innovative as it provides information about interest groups' access to policymaking in times of crisis. Moreover, it offers the first comprehensive comparison of interest groups' mobilization at the Spanish parliamentary and governmental arenas. In contrast to previous analyses (Dür and Mateo, 2016), our research does not rely on survey data, but on two datasets produced by the Quality of Democracy Research Group (www.q-dem. com). These datasets contain original data on registered interactions between interest groups and policymakers. More specifically, the datasets include detailed information about: (1) all interest groups' appearances in parliamentary committees in the Congreso de los Diputados; and (2) all the formal meetings between interest groups and members of the Spanish government from March 2020 to March 2021.

The article is structured as follows. Next section develops the theoretical discussion and defines the expectations that guide the empirical analysis. The third section contains a general description of the business associative movement in Spain, highlighting the leading business associations to date. The methodology is discussed in the fourth section, while the fifth section presents the results of the empirical analysis. The article ends by pointing out the main conclusions and commenting on future lines of research.

\section{BUSINESS GROUPS ACCESS TO POLICYMAKING}

In most advanced democracies, business associations participate in decision-making, regularly exchanging information and other resources with public authorities (Baumgartner et al., 2009; Bernhagen, 2007; Marsh and Lewis, 2013). Business groups' access to the policy process is institutionalized through formal and informal rules that define which policy actors are included and which functions they perform in each policy area (Richardson and Jordan, 1979; Marsh and Rhodes, 1992; McFarland, 2004; Chaqués-Bonafont, 2004). This provides business groups with a privileged position to inform policymakers about their preferences regarding policy problems and to monitor governmental activities (political decisions, legislative initiatives, and the implementation of policy programs) across time. ${ }^{2}$ By gaining access, business groups find a unique opportunity to provide facts about the magnitude of the policy process, to explain the content of technical reports about the consequences derived from different courses of action, and to argue about their members' preferences towards other policy options.

The dominance of business interests in the policy process is more evident in the governmental arena than the parliamentary one (Bell, 2012). According to, among

2. In parliamentary system, governments are under pressure to accurately and cunningly draft legislative projects and ministerial orders. Since governments pursue output legitimacy, they urge contacts with interest groups holding specific interests (business associations, professional associations). 
others, Dür and Mateo (2014) and Bouwen (2002), executive institutions and regulatory agencies have a greater demand for the type of information business groups can provide. Members of the executive need business groups' expertise to define political strategies, draft legislation and, on some occasions, they even participate directly in the implementation of policy solutions. In the same line, authors like Binderkrantz et al. (2015), Chaqués-Bonafont and Muñoz (2016) and Coen and Katsaitis (2013) argue that MPs have a lower demand for the technical information business groups can provide. The interaction between MPs and interest groups is oriented to discuss legislative proposals, governmental oversight activities, and political proposals. In doing so, MPs seek to give voice to different views and ways of thinking about policy issues and, ideally, to generate more public-oriented, consensual and thus more legitimate decisions.

Other authors argue that the interaction between MPs and interest groups is more open and fragmented than it is at the governmental arena, because it helps to ensure reelection (see Dür and Mateo, 2016: 154). The visibility and nature of the parliamentary activity encourages MPs to invite different interest groups (Eising and Spohr, 2017). On the one hand, citizens can follow interest groups' appearances on the Parliament TV channel, get the picture about the information interest groups provide in parliamentary hearings, and also their degree of commitment to defending specific causes. On the other hand, citizens can get quick and easy information about the MPs selection of interest groups to give evidence in Parliamentary hearings. In many parliamentary democracies, like Spain, parliamentary committees decide which groups come to testify, discussing legislative proposals, oversight activities, and policy proposals in general. In this context, limiting the access by interest groups to parliamentary audiences, especially those representing broad electoral districts, may generate significant political costs (Binderkrantz et al., 2015; Chaqués-Bonafont, 2020).

In contrast, interest groups participation at the governmental arena is opaque and far from public scrutiny. Government decisions are made behind closed doors and involve lengthy negotiations with an extensive network of actors. Citizens do not have systematic information about which interest groups participate in drafting legislation and allocating public money; nor they have information on lobbying interactions across policy areas. Interest groups often hide their true principles and goals, as there are no effective mechanisms to hold groups accountable for their actions. This generates a climate of discontent and criticism from the public opinion that some governments seek to correct through measures of transparency and good governance (Pedersen et al., 2014; Kohler-Koch et al., 2017), such as the publication of the members of government agendas.

Junk et al. (2021) have shown that the COVID-19 pandemic has reinforced the existing pattern of interaction between interest groups and policymakers across policy venues. In times of crisis, insider groups keep or even increase their access to policymakers. They also argue that citizen groups have fewer resources than business ones to mobilize and to convince the media, policymakers and public opinion about the importance of their demands. In contrast, the literature on "shock events" (LaPira, 
2014) and agenda-setting scholars (Baumgartner and Jones, 2005) suggest that times of crisis provide opportunities for new voices and new issues to emerge. In regular times, institutions can maintain stability and generate access dynamics based on resources, information, and trust between interest groups and public decision-makers. Dramatic events like the COVID-19 can transform existing interest groups-policymakers' relations by giving increasing access to other actors traditionally excluded from policymaking. This article brings some light to this open debate. Following the interest groups literature, we expect that:

$H 1$. Business groups interact with policymakers more intensely than other interest groups in the governmental arena.

H2. The interaction between business groups and members of Parliament is significantly lower than the former's interaction with members of government.

Business groups mobilize more intensely in policy areas that affect their interests, avoiding taking sides in discussions beyond their reach. As Coen and Grant emphasize, "business wants a stable political environment to plan and make long-run investment decisions, reducing investment costs and the risk of failure" (2006: 20). In other words, companies do not encourage business associations to take adventurous initiatives in times of crisis. Companies are concerned about their products, their markets, their profits, and their employees. Their involvement in the policy process focuses on policy areas that directly affect their interests, like agriculture, industry, or labor (Pakull et al., 2020; Hanegraaff and Berkhout, 2019). ${ }^{3}$ In contrast, social groups are prone to participate in open and conflictual processes, for or against policies as a whole (Baumgartner and Leech, 2001). Accordingly, we expect that:

H3. The interaction between business groups and policymakers is significantly larger in economic-related policy areas regardless of the political venue.

\section{WHO REPRESENTS BUSINESS DURING THE COVID-19 PANDEMIC?}

The COVID-19 pandemic is an excellent opportunity to investigate the representation of interests in Spain. There is little discussion in the literature on the leading role of the Confederación Española de Organizaciones Empresariales (CEOE) in representing business interests in Spain (see Aguilar, 2020). For decades, the CEOE has enjoyed the undisputed recognition by the media, unions and political class as the most representative

3. Employers tend to focus on very specific aspects of policies, clearly bearing in mind the costs of their collective action. This implies that sectoral business associations concentrate their activity in Ministries and in parliamentary committees likely to bring them selective benefits such as agriculture, industry, or labor. 
business associations. Given the lack of official records on business associations' membership and access, the CEOE has based its prestige on a series of agreements made during the transition to democracy in the late 1970s. The CEOE was created in 1977 as a statewide peak business association ${ }^{4}$ to negotiate with the unions on labor relations and to advise policymakers across policy areas, mainly trade and industry.

CEOE's influential role stems from several factors. First, article 7 of the 1978 Spanish Constitution granted a central status to business associations and trade unions in a context of economic crisis and worker unrest. It is by law that the political institutions must guarantee business associations' institutional participation and allow them to negotiate with the unions on collective agreements. Second, the CEOE has become the most representative association after blocking other business associations' political aspirations. The CEOE confronted the Chambers of Commerce ${ }^{5}$ for decades until the 2007-08 crisis, when the Spanish government abolished the compulsory membership in the Chambers of Commerce ${ }^{6}$, thus causing a profound impact on the Chambers' associative structure and functions. And third, in the 1990s and 2000s, Spain's entry into the European Union and its economic modernization posed a series of challenges and tensions for Spanish companies: Traditional sectors such as agriculture had to adapt to the new European regulations, while large companies contended with European politics ${ }^{7}$.

The CEOE has faced several challenges in the last two decades, albeit with mixed results. A first challenge relates to the increasing political autonomy of the CEOE territorial branches after the reform of the Statutes of Autonomy of several regional governments (or Autonomous Communities) (Medina, 2016). A second challenge derives from the 2007-08 financial crisis. Large companies created their lobbying platforms outside the $\mathrm{CEOE}^{8}$, like the Consejo Empresarial para la Competitividad in 2017; although its recent dismantling suggests that this challenge has cooled down. A third challenge is taking place during the COVID-19 pandemic. New self-employed entrepreneurs' associations such as ATA, UATAE, and UPTA ${ }^{9}$ have gained momentum in the public debate as the Spanish government began regulating self-employed workers'

4. This means the CEOE is an association that represents other sectoral and territorial associations at state level throughout the Spanish territory.

5. The Chambers of Commerce took a decisive role in launching proposals on issues such as infrastructures, training, international trade, and taxation.

6. For more details on the topic, see the Real Decreto-Ley 13/2010 and the Ley 4/2014, de 1 de abril, Básica de las Cámaras Oficiales de Comercio, Industria, Servicios y Navegación.

7. Large companies began to demand greater freedom of negotiation in labor relations that would allow them to gain international competitiveness.

8. It is important to remember that the CEOE does not allow direct affiliation of individual companies.

9. These are the acronyms for Federación Nacional de Asociaciones de Empresarios y Trabajadores Autónomos (ATA), Unión de Asociaciones de Trabajadores Autónomos y Emprendedores (UATAE), and Unión de Profesionales y Trabajadores Autónomos (UPTA). 
fiscal and labor conditions in May $2021^{10}$. Moreover, the Chambers of Commerce have recovered media presence after incorporating large companies into decision-making bodies and consolidating their budgets thanks to new public subsidies ${ }^{11}$ (Medina and Molins, 2021).

In sum, the CEOE has shown a historical capacity to reduce competition within business associations at the state level, especially regarding labor relations and the general discussions about the industrial policy. During the pandemic, the CEOE has negotiated with the government and trade unions on key issues such as labor conditions (telework and flexible schedules, self-employed delivery workers law, increase in the minimum wage), economic issues (European Funds), and social security matters (pension reform, retirement, temporary regulation of jobs) (Belzunegui-Eraso and Erro-Garcés, 2020; Rodríguez, 2020). The COVID-19 crisis has forced the government and social partners to change their priorities concerning the agenda of reforms initially established in December 2019 (Molina, 2021: 8). However, the COVID-19 did not erode the existing corporatist negotiation structures (Gómez Funes, 2020). Thus, we expect that:

H4. The CEOE and its sectoral associations have monopolized the representation of business interests during the pandemic in all policy areas.

\section{DATA AND METHODS}

The empirical strategy relies on the two datasets developed by the Quality of Democracy Research Group (www.q-dem.com). One dataset gathers information about interest groups' appearances in parliamentary committees. These are regulated in the statutes of the Congreso de los Diputados (articles 44 and 53) ${ }^{12}$, which empower parliamentary commissions to invite interest groups to give evidence about policy proposals, legislative initiatives, or policy oversight activities. The dataset contains information about all appearances from 1996 to 2021. For each interest group's hearing (comparecencia), the dataset contains information about the person who participates in the hearing, the organization they represent (if any), the date, the name of the parliamentary committee, and the issue of the parliamentary hearing ${ }^{13}$. To

10. Real Decreto-ley 11/2021, de 27 de mayo, sobre medidas urgentes para la defensa del empleo, la reactivación económica y la protección de los trabajadores autónomos.

11. However, the Law on Chambers of Commerce approved in 2014 under the conservative government of Mariano Rajoy limited the political functions of the Spanish Chamber of Commerce to turn it into a platform dedicated to the foreign promotion of Spanish companies.

12. Please visit the following website for more information: https://www.congreso.es/web/guest/ cem/reglam.

13. It has to be noted that in the case of education, all appearances related to the discussion of the Organic Law on education were cancelled. As for several other policy areas (Defense; Inclusion, 
gather all this information, we have used the archives of the Congreso de los Diputados, available at www.congreso.es.

The second dataset contains information about the interaction between interest groups and members of government during the pandemic. We collected data from the agendas of all Ministries and the President of government, available at the Moncloa website (www.lamoncloa.gob.es). Twenty-four agendas have been analyzed: twenty-three of them correspond to each ministry, and one more is the President of government's agenda. Each agenda offers daily information of any formal contact between a Ministry and interest groups, be it either an event organized by an interest group (i.e. participation in seminars and conferences) or a working meeting. Although the dataset distinguishes between these two types of interactions, we only examine the latter kind $^{14}$. The data was collected daily since there is no downloadable file containing all the information. The agendas report all public activity developed by the government members.

The period of analysis is from March 2020 to March 2021. This time frame starts with the decision to confine the entire Spanish population. The central government negotiated the conditions to reactivate the economy with hundreds of groups and international authorities throughout the year, while the regional governments agreed on the health measures. March 2021 was set as the end of the period analyzed because then took place a restructuring of the government which altered the heads of some ministries and the distribution of some competencies among them.

All information has been classified as follows: Similarly to what has been done in previous research projects like Baumgartner et al. (2009), the INTEREURO (Beyers et al., 2014), INTERARENA (Binderkrantz et al., 2020) and Chaqués-Bonafont and Muñoz (2016), interest groups are here classified into six categories, namely, (1) business groups, (2) unions, (3) citizens and cause-oriented groups, (4) professional associations, (5) companies, and (6) other groups (which include experts and think-tanks). Moreover, policy areas are classified according to the comparative agendas project methodology. The division of labor across Ministries and parliamentary committees during the pandemic has also been taken into consideration. As it occurs in most parliamentary democracies, the parliamentary committees mirror the division of labor within government. Thus, there is a parliamentary committee for each ministry. As table 1 in the appendix illustrates, non-permanent parliamentary committees have also been included in the analysis. Among those non-permanent committees, it is particularly relevant the Comisión para la Reconstrucción Social y Económica, which was created to respond to the challenge of the COVID-19 pandemic and structured

social security and migrations; Presidency; Relations with the parliament and Democratic Memory; and Universities), interest groups interventions only take place in the governmental arena, but not in the parliamentary one.

14. In our opinion, these events are relevant to study the acquisition of insider status, but they explain aspects related to access in a very diffuse way. 
into four subcommittees: social issues (including health-related issues), the economy, social policy, and cooperation with the European Union.

\section{BUSINESS GROUPS IN TIMES OF CRISIS}

From March 2020 to March 2021, members of Parliament organized 491 hearings with interest groups to discuss legislative proposals, as well as monitor and advise governmental activities. About $37 \%$ of interest groups' appearances were oriented to discuss the economic and social consequences of the COVID-19 pandemic. The rest were aimed to discuss bills ${ }^{15}$ (about $14 \%$ of all interest groups appearances) and other policy priorities apart from legislative proposals and the COVID-19 pandemic ( $49 \%$ of the interest groups appearances). Members of Parliament wanted interest groups to provide technical and political information about the consequences of the Brexit, the updating of the regulatory framework of the International Development Cooperation system and the Spanish strategy to achieve the Sustainable Development Goals.

Members of the government met interest groups 679 times. Some ministries sporadically interacted with interest groups (like Treasury, Transportation, Defense, Interior), while others maintained weekly interactions. This is the case of the Ministries of agriculture, trade, justice, labor, and to a lesser extent education. These results already inform there are significant differences regarding the policy issues members of government and Parliament discuss with interest groups. In Parliament, interest groups have been requested to give evidence about EU policy, a policy area where the executive enjoys a predominant position in setting the agenda. In the governmental arena, most interactions are between interest groups and the ministries of trade or agriculture. They are mainly oriented to get detailed information about the consequences of the COVID-19 pandemic in economic sectors and to define strategic plans to respond to it.

Table 1 indicates that business groups have a predominant position in the discussion of most issues in the governmental arena, but not in the parliamentary arena. Business groups met 257 times with members of the government considering both events and working meetings — this is, almost every working day, a business group

15. The legislative proposals are the following: Proyecto de Ley de cambio climático y transición energética; Proyecto de Ley por la que se modifica la Ley 12/2013, de 2 de agosto, de medidas para mejorar el funcionamiento de la cadena alimentaria; Proposición de Ley de modificación de la Ley 39/2006, de 14 de diciembre, de Promoción de la Autonomía Personal y Atención a las personas en situación de dependencia; Proyecto de Ley Orgánica de protección integral a la infancia y la adolescencia frente a la violencia; Proposición de Ley sobre ratios de enfermeras para garantizar la seguridad del paciente en centros sanitarios y otros ámbitos. It has also to be noted that interests group hearings scheduled to discuss the proyecto de ley orgánica de modificación de la LOE were never celebrated because the two governing parties, together with other political forces, banned their celebration. 
had an appointment scheduled with a member of government during the period under analysis. The access to the government by business groups doubles those of citizen groups, unions or professional groups. Differences are significant regarding companies and other groups, which include individual experts and think-tanks. In contrast, only twenty percent of interest groups appearances in parliamentary committees are carried out by business groups. MPs mostly rely on individual experts and think tanks to get information about policy issues. More than forty percent of the interest groups appearances in parliamentary committees involve individual experts and think tanks, followed by the appearances by citizens, ideological and cause-oriented groups (NGOs), which account for twenty six percent of interest groups' appearances. Companies, unions, and professional associations account for less than four percent of the appearances in Parliamentary committees each.

TABLE 1.

Interest groups, interactions with the government and Parliament, March 2020MARCH 202 I

\begin{tabular}{lcccc}
\hline \multirow{2}{*}{ Interest groups } & \multicolumn{2}{c}{ Government } & \multicolumn{2}{c}{ Parliament } \\
\cline { 2 - 5 } & $\mathbf{N}$ & $\mathbf{\%}$ & $\mathbf{N}$ & $\mathbf{\%}$ \\
\hline Business associations & 257 & $38 \%$ & 96 & $20 \%$ \\
\hline Citizen, ideological or cause-oriented group (NGO) & 112 & $16 \%$ & 126 & $26 \%$ \\
\hline Professional associations & 107 & $16 \%$ & 22 & $4 \%$ \\
\hline Unions & 104 & $15 \%$ & 25 & $5 \%$ \\
\hline Other (experts and think tanks) & 62 & $9 \%$ & 209 & $43 \%$ \\
\hline Companies & 37 & $5 \%$ & 13 & $3 \%$ \\
\hline Total & 679 & $100 \%$ & 491 & $100 \%$ \\
\hline
\end{tabular}

Source: Own elaboration based on data collected by Q-Dem (www.q-dem.com).

We compare the mean percentage of times each type of interest group gets access to the parliamentary and governmental arena across thirteen policy areas (see table 1 in the appendix). As Figure 1 illustrates, business groups interact significantly more with government members than with MPs (the mean number of meetings between business groups and MPs is almost half that with government members). The same applies to professional associations and trade unions. The mean number of meetings between ministries and unions is three times higher than with MPs; and differences are even more significant in the case of professional associations. In contrast, citizens' participation and cause-oriented groups follow a similar pattern at both governmental and parliamentary arenas. The same occurs in the case of companies. In both political arenas, and in contrast to the economic recession, the participation of companies in political discussions during the COVID-19 is relatively marginal. Finally, results indicate that individual experts have interacted thirty-two times with MPs on average across the thirteen policy areas, more than twice the interactions with government members. 
Figure 1.

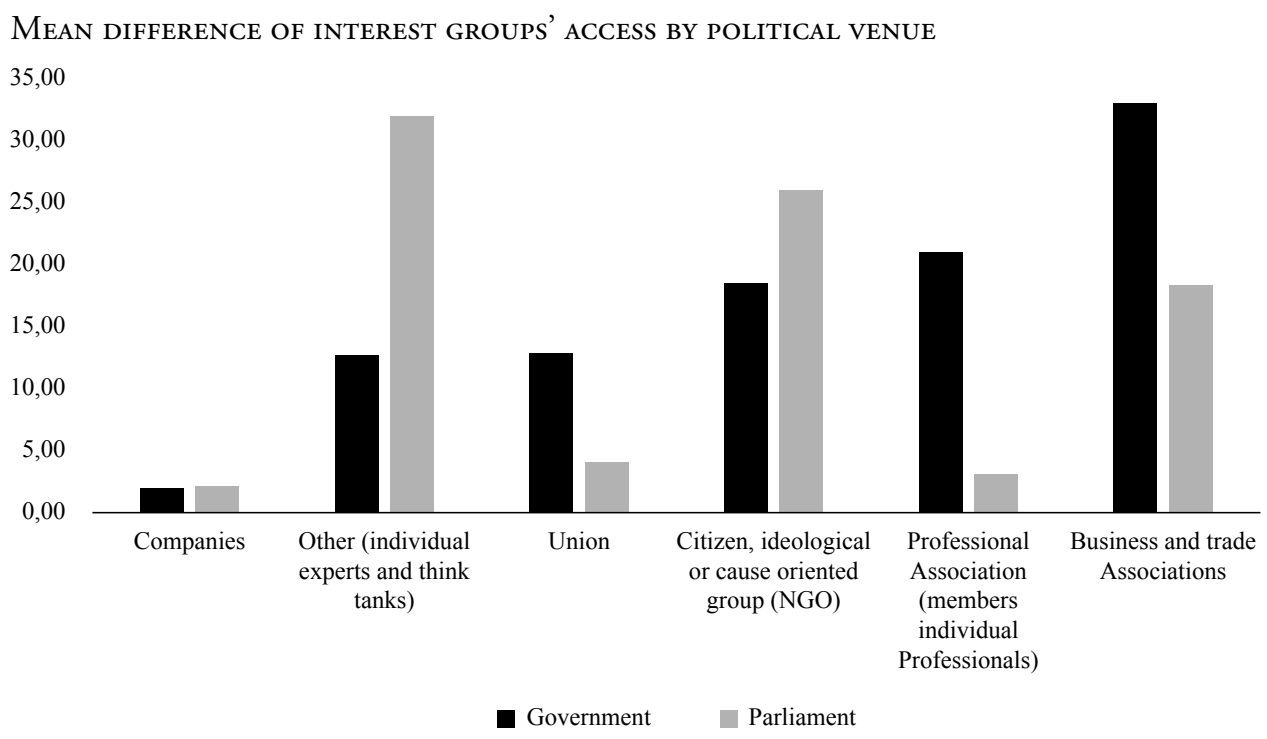

Source: Own elaboration based on data collected by Q-Dem (www.q-dem.com).

Overall, these results confirm our first hypothesis. Business groups have a predominant position in the policy process, and this is especially the case in the governmental arena. The next question is whether business group's dominant position applies across policy areas. Figure 2 summarizes the percentage of times each kind of interest groups has got access to the governmental and parliamentary venues across policy areas. The results show that business groups almost monopolize the representation of interests in agriculture, economy, trade and banking. Most parliamentary discussions $(93,3 \%)$ about issues related to agriculture are discussed with business associations. Agriculture business associations account for $71,7 \%$ of the meetings with government members, mainly with the Ministry of Agriculture.

The mobilization of business interests is strong in those policy areas where there are highly professionalized associations. This is the case of agriculture and fishing with the Asociación Agraria de Jóvenes Agricultores (ASAJA), the Coordinadora de Organizaciones de Agricultores y Ganaderos (COAG) and many fishermen's associations (the so-called cofradias). The same occurs in the fields of trade and banking. Two-thirds of the working meetings between Ministries and interest groups involved business groups. The associations with greater access in these matters were the CEOE (eleven times) and CEPYME (seven times), followed by the Cámara de Comercio de España (four times) and AMETIC (four times), which is the business association that represents telecommunications companies. In the case of parliamentary hearings, more than fifty percent of interest groups that gave evidence in parliamentary hearings were business associations. 
FiguRE 2.

INTEREST GROUPS' ACCESS TO GOVERNMENTAL AND PARLIAMENTARY VENUES ACROSS POLICY AREAS, MARCH 2020-MARCH $202 \mathrm{I}$
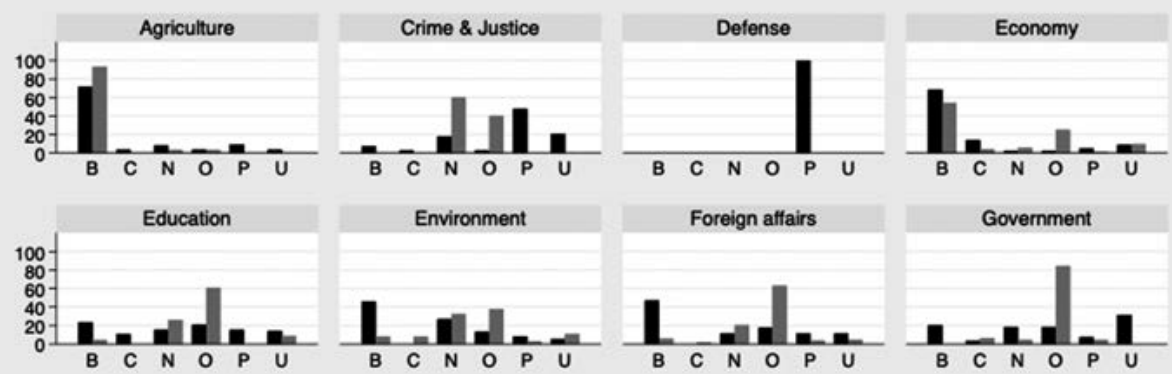

Foreign affairs

Government
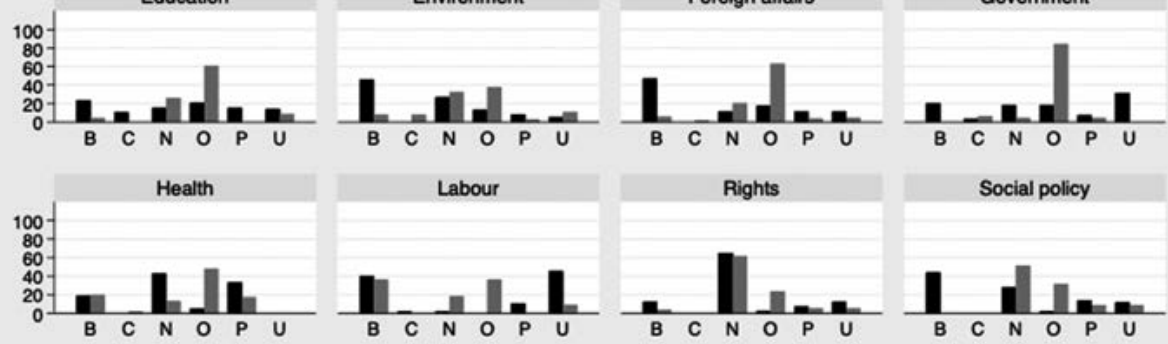

Rights

Social policy
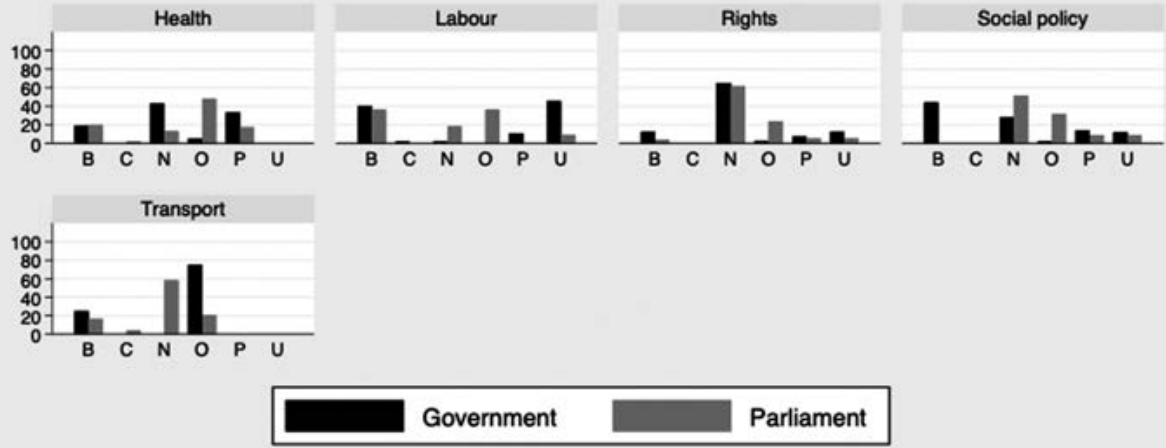

Note: B: business groups; C: companies; N: citizens and cause-oriented groups (NGOs); O: Individual experts and think tanks; P: professional associations; U: unions.

Source: Own elaboration based on data collected by Q-Dem (www.q-dem.com).

The presence of business groups is also relevant in other policy areas like foreign affairs, the environment, and the social security system (social policy), which account for more than forty percent of interactions between a ministry and interest groups. In particular, the Ministry of Inclusion, Social Security, and Immigration met eighteen times with business groups, primarily representatives of self-employed entrepreneurs (ATA, UPTA, UATAE) ${ }^{16}$ and the CEOE, to discuss matters related to pensions and social security contributions. In contrast, MPs never invited business groups to give evidence on social policy; arguably because discussions on social policy in Parliament revolved around the extension of social rights and not on social security issues. The presence of business in parliamentary debates about defense, crime, and justice, education,

16. Federación Nacional de Asociaciones de Empresarios y Trabajadores Autónomos (ATA), Unión de Asociaciones de Trabajadores Autónomos y Emprendedores (UATAE), and Unión de Profesionales y Trabajadores Autónomos (UPTA). 
rights, or governmental affairs is almost null. This invites us to think about the autonomy of both institutions when considering which issues are relevant and which private actors are essential to carry out their political functions. Finally, in the case of labor, transportation, or health, business groups' participation is quite similar in both political scenarios.

Next, we explore which organizations represent business interests. Our goal is to examine the ability of the $\mathrm{CEOE}$ and its sectoral associations to monopolize the representation of business interests vis-à-vis other business associations. Data indicates that the CEOE and its sectoral associations have not dominated the representation of business interests during the pandemic. Both the government and parliamentary groups have allowed access to many business associations that are outside the CEOE structure. The CEOE and its sectoral associations became the preferred interlocutors virtually half the times that a business association accessed those institutions. This means there are business interests that the CEOE does not represent in the policy process. Table 2 indicates that this is the case for self-employed businesspersons, agricultural entrepreneurs, SMEs, and some multinational companies. The truth is that the CEOE has failed to catapult its associations of self-employed entrepreneurs (ATA), farmers (ASAJA), and SMEs (CEPYME). These sectors have been fertile in creating associations of a nature other than strictly business interests (i.e. territory, ideology).

TABLE 2.

BUSINESS ASSOCIATIONS WITH A HIGHER NUMBER OF WORKING MEETINGS WITH GOVERNMENT

\begin{tabular}{lcc}
\hline Business Association & N & Sector \\
\hline CEOE and its member associations & & \\
\hline Confederación Española de Organizaciones Empresariales (CEOE) & 18 & Peak \\
\hline Confederación Española de la Pequeña y Mediana Empresa (CEPYME) & 16 & Peak \\
\hline $\begin{array}{l}\text { Federación Nacional de Asociaciones de Empresarios y Trabajadores } \\
\text { Autónomos (ATA) }\end{array}$ & 7 & Self-employed \\
\hline Asociación Espańola de Fabricantes de Automóviles y Camiones (ANFAC) & 5 & Automobile \\
\hline $\begin{array}{l}\text { Asociación Española de Distribuidores, Autoservicios y } \\
\text { Supermercados (ASEDAS) }\end{array}$ & 4 & Supermarkets \\
\hline Confederación Española de Pesca (CEPESCA) & 4 & Fishery \\
\hline Alianza por la Competitividad de la Industria Espańola & 3 & Industry \\
\hline Asociación Agraria de Jóvenes Agricultores (ASAJA) & 3 & Agriculture \\
\hline Asociación de Cadenas Españolas de Supermercados (ACES) & 3 & Supermarkets \\
\hline Asociación Nacional de Grandes Empresas de Distribución (ANGED) & 3 & Supermarkets \\
\hline Other business associations & & \\
\hline $\begin{array}{l}\text { Unión de Asociaciones de Trabajadores Autónomos y Emprendedores } \\
\text { (UATAE) }\end{array}$ & 7 & Self-Employed \\
\hline Unión de Profesionales y Trabajadores Autónomos (UPTA) & 7 & Self-Employed \\
\hline & &
\end{tabular}


.../...

\begin{tabular}{lcc}
\hline Business Association & N & Sector \\
\hline Confederación Empresarial Española de la Economía Social (CEPES) & 5 & Peak SMEs \\
\hline Cooperativas Agroalimentarias de España & 4 & Agriculture \\
\hline Multinacionales por la Marca España (Pormarca_España) & 4 & Multinationals \\
\hline Unión de Pequeños Agricultores y Ganaderos (UPA) & 3 & Agriculture \\
\hline
\end{tabular}

Source: Own elaboration based on data collected by Q-Dem (www.q-dem.com).

The list of business associations that access the Parliament (Table 3) allows us to identify an exciting dynamic. While the CEOE has managed to position its sectoral associations among the associations with the highest frequency of contacts with the government, parliamentary groups are not bound by "representative hierarchy" when it comes to inviting business associations to deal with sectoral issues. Parliamentary groups hear alternative voices as much as outsider associations are dedicated to building bridges with political parties to acquire more political capital. In this vein, the literature already noted that business associations find little incentives to engage in long-range debates in the Parliament. CEOE and CEPYME preferentially have assumed this role to avoid exposing their sectoral associations to such contradictory situations.

TABLE 3.

BUSINESS ASSOCIATIONS WITH A HIGHER NUMBER OF PARLIAMENTARY APPEARANCES

\begin{tabular}{lcc}
\hline Business Association & N & Sector \\
\hline CEOE and its member associations & & \\
\hline Confederación Española de Organizaciones Empresariales (CEOE) & 5 & Peak \\
\hline Asociación de Empresas con Gran Consumo de Energía (AEGE) & 3 & Industry \\
\hline $\begin{array}{l}\text { Confederación Española de la Pequeña y Mediana Empresa } \\
\text { (CEPYME) }\end{array}$ & 3 & Peak \\
\hline Alianza por la Competitividad de la Industria Española & 2 & Industry \\
\hline Asociación Agraria de Jóvenes Agricultores (ASAJA) & 2 & Agriculture \\
\hline $\begin{array}{l}\text { Asociación Española de Distribuidores, Autoservicios y } \\
\text { Supermercados (ASEDAS) }\end{array}$ & 2 & Supermarkets \\
\hline $\begin{array}{l}\text { Asociación Española de Fabricantes de Automóviles y Camiones } \\
\text { (ANFAC) }\end{array}$ & 2 & Automobile \\
\hline Confederación Española de Comercio (CEC) & 2 & Trade \\
\hline Federación Empresarial Industria Química Española (FEIQUE) & 2 & Chemicals \\
\hline Federación Española de Industrias de Alimentación y Bebidas (FIAB) & 2 & Food \\
\hline Other business associations & 3 & SMEs \\
\hline Petita i Mitjana Empresa de Catalunya (Pimec) & 3 & \\
\hline
\end{tabular}




\begin{tabular}{lcc}
.../... & N & Sector \\
\hline Business Association & 2 & Travel agencies \\
\hline Asociación Corporativa de Agencias de Viajes Especializadas (ACAVE) & 2 & Textile \\
\hline $\begin{array}{l}\text { Asociación Empresarial del Comercio Textil Complementos y Piel } \\
\text { (ACOTEX) }\end{array}$ & 2 & Commerce \\
\hline Cámara de Comercio de Espańa & 2 & Agriculture \\
\hline Coordinadora de Organizaciones de Agricultores y Ganaderos (COAG) & 2 & Metal \\
\hline Federación Empresarial del Metal (FEM) & 2 & Fishery \\
\hline Federación Nacional de Cofradías de Pescadores (FNCP) & 2 & Hostelry \\
\hline Plataforma Hostelería con Conciencia & 2 & Commerce \\
\hline Unió d'Entitats de Comerç de Catalunya RETAILcat & 2 & Agriculture \\
\hline Unión de Pequeńos Agricultores y Ganaderos (UPA) & 2 & Agriculture \\
\hline Unión de Profesionales y trabajadores autónomos (UPTA) & 2 & Agriculture \\
\hline Unión de Uniones de Agricultores y Ganaderos & &
\end{tabular}

Source: Own elaboration based on data collected by Q-Dem (www.q-dem.com).

Figure 3.

DisTRIBUTION OF MEETINGS AND PARLIAMENTARY HEARINGS BETWEEN THE CEOE AND OTHER

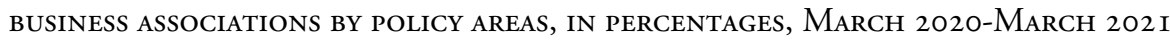

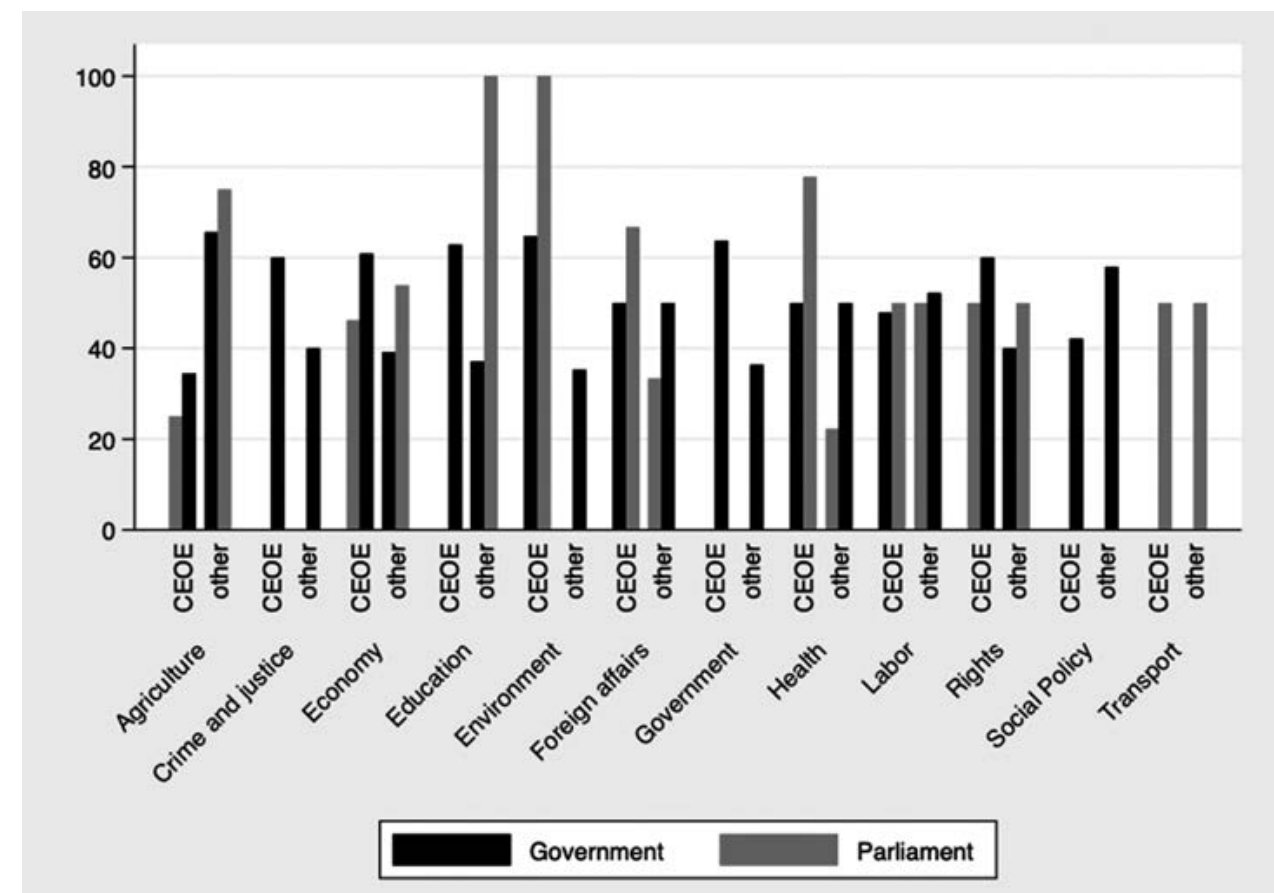

Source: Own elaboration based on data collected by Q-Dem (www.q-dem.com). 
A final relevant indicator shown in Figure 3 is the distribution of formal meetings and parliamentary appearances by policy area. At first glance, the CEOE shares representation spaces with other associations in most Ministries and parliamentary committees. The government areas where the CEOE obtains a more significant presence do not coincide with the parliamentary committees, reinforcing the autonomy between institutions to form their policy networks. Economy, agriculture, education, and labor are the governmental areas that have held the highest number of meetings during the pandemic. The CEOE seems to enjoy more significant power in economic-related affairs thanks to its sectoral associations. Yet, data for agriculture shows that the CEOE competes with other associations to define policy. The competition in these areas is transferred to the Parliament, where the number of appearances by the CEOE does not exceed those by the rest of the associations that do not belong to it.

\section{CONCLUSION}

Business groups have occupied a predominant position in discussing policy proposals vis-à-vis other types of groups during the COVID-19 pandemic in the governmental arena, but not the parliamentary arena. Most meetings between members of the Spanish executive and interest groups have involved business associations. The article also demonstrates that the predominant business position in the governmental arena varies significantly across policy areas. Some Ministries, like those for agriculture or trade, maintained weekly contacts with a plurality of business organizations. In contrast, the ministry of defense, the treasury, internal security, or the ministry of higher education rarely met business groups during the pandemic. Differences in the involvement of business groups across Ministries are not explained by the level of professionalization of business organizations or the members of government's ideological preferences, but it seems related to the functions the various ministries perform.

In contrast, most of the interactions between interest groups and members of Parliament have been with individual experts, citizens and cause-oriented groups. This corroborates existing research about the presence of business groups across political venues. MPs do not invite business groups to participate in parliamentary hearings dealing with political corruption, the environment, rights-related issues, social policy, crime, or education. Business groups' participation in the parliamentary arena is highly concentrated in three policy areas: industrial policy, agriculture, and to a lesser extent health-related issues. Finally, these results inform the COVID-19 did not alter the presence of business groups in the parliamentary arena. As in previous decades, business groups do not have a predominant position in the parliamentary arena, especially for non-economic policy areas.

Finally, the article argues the CEOE's predominant position in the policymaking process remains indisputable. The CEOE has always sought to expel rival associations from the institutions (i.e. the Chambers of Commerce), but it has not been able to avoid the presence of agricultural associations, self-employed associations, and SME 
associations that are not part of its organizational structure. It is too early to assess whether these events will impact on the number of relevant peak business associations in the coming years, especially on the CEOE's commitment to reaching agreements with the left-wing government or aligning itself decisively with conservative political forces. In any case, a new peak SMEs business association called CONPYMES was created in May 2021 by the Unión de Asociaciones de Trabajadores Autónomos y Emprendedores (UATAE) and the Catalan PIMEC with the aim of rivaling the CEOE in the labor and economic spheres. ${ }^{17}$ The new association has received the public support of left-wing parties and Catalan nationalist parties. From past experiences, we know that the CEOE's reaction to other similar projects was highly belligerent.

\section{References}

Aguilar, Susana. 2020. "Interest groups, business associations and trade unions", in D. Muro and I. Lago (eds.) The Oxford Handbook of Spanish Politics. Oxford: Oxford University Press. Available at: https://doi.org/10.1093/oxfordhb/978019 8826934.013.25.

Baumgartner, Frank R. and Beth L. Leech. 2001. "Interest Niches and Policy Bandwagons: Patterns of Interest Group Involvement in National Politics", The Journal of Politics, 63: 1191-1213. Available at: https://doi.org/10.1111/0022-3816.00106.

Baumgartner, Frank R. and Bryan Jones. 2005. The Politics of Attention: How Government Prioritizes Problems. Chicago: University of Chicago Press.

Baumgartner, Frank R., Jeffrey M. Berry, Marie Hojnacki, Beth L. Leech and David C. Kimball. 2009. Lobbying and policy change: Who wins, who loses, and why. Chicago, IL: University of Chicago Press. Available at: https://doi.org/10.7208/ chicago/9780226039466.001.0001.

Bell, Stephen. 2012. “The Power of Ideas: The Ideational Shaping of the Structural Power of Business", International Studies Quarterly, 56: 661-673. Available at: https://doi.org/10.1111/j.1468-2478.2012.00743.x.

Belzunegui-Eraso, Ángel and Amaya Erro-Garcés. 2020. "Teleworking in the Context of the COVID-19 Crisis", Sustainability, 12 (9): 1-18. Available at: https://doi. org/10.3390/su12093662.

Bernhagen, Patrick. 2007. The Political Power of Business: Structure and Information in Public Policymaking. London: Routledge. Available at: https:/doi. org/10.4324/9780203932612.

Beyers, Jan, Laura Chaqués-Bonafont, Andreas Dür, Rainer Eising, Danika FinkHafner, David Lowery, William Mahoney, Chistine Maloney and Daniel Naurin. 2014. "The INTEREURO Project: Logic and structure", Interest Groups and Advocacy, 3 (2): 126-140. Available at: https://doi.org/10.1057/iga.2014.8.

17. Available at: https://cutt.ly/4Tc6ffD. 
Binderkrantz, Anne S., Peter M. Christiansen and Helene H. Pedersen. 2015. "Interest Group Access to the Bureaucracy, Parliament, and the Media”, Governance, 28 (1): 95-112. Available at: https://doi.org/10.1111/gove.12089.

Binderkrantz, Anne S., Peter M. Christiansen and Helene H. Pedersen. 2020. "Mapping interest group access to politics: a presentation of the INTERARENA research project", Interest Groups and Advocacy 9 (3): 290-301. Available at: https://doi.org/10.1057/s41309-020-00095-9.

Bouwen, Pieter. 2002. "Corporate lobbying in the European Union: The logic of access”, Journal of European Public Policy, 9 (3): 365-390. Available at: https://doi. org/10.1080/13501760210138796.

Chaqués-Bonafont, Laura. 2004. Redes de politicas públicas. Madrid: Centro de Investigaciones Sociológicas.

Chaqués-Bonafont, Laura. 2020. "Interest groups and political representation”, in M. Cotta and F. Russo (eds.), Handbook of Political Representation. Edward Elgar Publishing. Available at: https://doi.org/10.4337/9781788977098.00033.

Chaqués-Bonafont, Laura and Luz M. Muñoz. 2016. "Explaining interest group access to parliamentary committees", West European Politics, 39 (6): 1276-1298. Available at: https://doi.org/10.1080/01402382.2016.1184862.

Coen, David and Alexander Katsaitis. 2013. "Chameleon pluralism in the EU: an empirical study of the European Commission interest group density and diversity across policy domains", Journal of European Public Policy 20 (8): 1104-1119. Available at: https://doi.org/10.1080/13501763.2013.781785.

Coen, David and Wyn Grant. 2006. "Managing business and government relations”, in D. Coen and W. Grant (eds.), Business and Government: Methods and Practice. IPSA 2000 Series. Opladen: Barbara Budrich. Available at: https://doi. org/10.2307/j.ctvddzw1n.

Coen, David, and Jeremy Richardson (eds.). 2009. Lobbying the European Union: Institutions, Actors, and Issue. New York: Oxford University Press.

Dür, Andreas and Gemma Mateo. 2013. "Gaining Access or Going Public? Interest Group Strategies in Five European Countries", European Journal of Political Research 52 (5): 660-686. Available at: https://doi.org/10.1093/acprof:oso/9780 198785651.001 .0001$.

Dür, Andreas and Gemma Mateo. 2016. Insiders versus Outsiders: Interest Group Politics in Multilevel Europe. Oxford: Oxford University Press. Available at: https:// doi.org/10.1093/acprof:oso/9780198785651.001.0001.

Dür, Andreas, David Marshall and Patrick Bernhagen. 2019. The Political Influence of Business in the European Union. Ann Arbor: University of Michigan Press.

Eising, Rainer and Florian Spohr. 2017. "The More, the Merrier? Interest Groups and Legislative Change in the Public Hearings of the German Parliamentary Committees", German Politics, 26 (2): 314-333. Available at: https://doi.org/10.1080/096 44008.2016.1213244.

Fraussen, Bert, Jan Beyers and Tom Donas. 2015. "The Expanding Core and Varying Degrees of Insiderness: Institutionalised Interest Group Access to Advisory Coun- 
cils", Political Studies, 63 (3): 569-588. Available at: https://doi.org/10.1111/ 1467-9248.12112.

Gilens, Martin and Benjamin I. Page. 2014. "Testing Theories of American Politics: Elites, Interest Groups, and Average Citizens", Perspectives on Politics, 12 (3): 564-581. Available at: https://doi.org/10.1017/S1537592714001595.

Gómez Funes, Andrés. 2020. Generación, género y tecnología en las organizaciones empresariales españolas (1998-2018) [unpublished $\mathrm{PhD}$. Dissertation].

Hanegraaff, Marcel and Joost Berkhout. 2019. "More business as usual? Explaining business bias across issues and institutions in the European Union", Journal of European Public Policy, 26 (6): 843-862. Available at: https://doi.org/10.1080/13 501763.2018.1492006.

Junk, Wiebke M., Michele Crepaz, Marcel Hanegraaff, Joost Berkhout and Ellis Aizenberg. 2021. "Changes in interest group access in times of crisis: no pain, no (lobby) gain”, Journal of European Public Policy. Available at: https://doi.org/10.1 080/13501763.2021.1968936.

Kohler-Koch, Beate, Peter Kotzian and Christine Quittkat. 2017. "The Multilevel Interest Representation of National Business Associations", West European Politics, 40 (5): 1046-1065. Available at: https://doi.org/10.1080/01402382.2017.1 303244.

LaPira, Timothy M. 2014. "Lobbying after 9/11: Policy regime emergence and interest group mobilization", Policy Studies Journal, 42 (2): 226-251. Available at: https://doi.org/10.1111/psj.12057.

Marsh, David and Chris Lewis. 2013. "The Political Power of Big Business: A Response to Bell and Hindmoor", New Political Economy, 19 (4): 628-633. Available at: https://doi.org/10.1080/13563467.2013.829435.

Marsh, David and R. A. W. Rhodes (eds.). 1992. Policy Networks in British Government. Oxford: Clarendon Press. Available at: https://doi.org/10.1093/acprof:oso/ 9780198278528.001 .0001$.

McFarland, Andrew S. 2004. Neopluralism: The Evolution of Political Process Theory. Lawrence, KS: University Press of Kansas.

Medina, Iván. 2016. "Are Business Associations Involved in Regional Politics? Evidence from Spain and the United Kingdom", European Urban and Regional Studies, 23 (3): 389-405. Available at: https://doi.org/10.1177/0969776413513603.

Medina, Iván and Joaquim M. Molins. 2021. "Institutional Change in Spanish Chambers of Commerce", in D. Sack (ed.), Chambers of Commerce in Europe. Cham: Palgrave Macmillan. Available at: https://doi.org/10.1007/978-3-03062700-3_5.

Molina, Oscar. 2021. Spain: Working life in the COVID-19 pandemic 2020. Eurofund Working Paper.

Pakull, Dominic, David Marshall and Patrick Bernhagen. 2020. "Shop till you drop? Venue choices of business and non-business interests in the European Union", Interest Groups and Advocacy, 9: 520-540. Available at: https://doi.org/10.1057/ s41309-020-00092-y. 
Pedersen, Helene H., Anne S. Binderkrantz and Peter M. Christiansen. 2014. "Legislative Process in Denmark", Legislative Studies Quarterly, 39: 199-225. Available at: https://doi.org/10.1111/lsq.12042.

Rhodes, R. A. W. 2006. "Policy Network Analysis", in M. Moran, M. Rein and R. E. Goodin (eds.), The Oxford Handbook of Public Policy. Oxford: Oxford University Press.

Richardson, Jeremy and Grant Jordan. 1979. Governing Under Pressure. Oxford: Martin Roberson.

Rodríguez, Diego. 2020. Teletrabajo, acceso a Internet y apoyo a la digitalización en el contexto del COVID-19. FEDEA report, No. 2020-08.

Salisbury, Robert H. 1969. "An Exchange Theory of Interest Groups”, Midwest Journal of Political Science, 13 (1): 1-32. Available at: https://doi.org/10.2307/2110212.

Schattschneider, Elmer E. 1960. The Semisovereign People: A Realist's View of Democracy in America. New York, NY: Holt, Rinehart and Winston.

Schneider, Volker. 2006. "Business in Policy Networks: Estimating the Relative Importance of Corporate Direct Lobbying and Representation by Trade Associations", in D. Coen and W. Grant (eds.), Business and Government: Methods and Practice. IPSA 2000 Series. Opladen: Barbara Budrich. Available at: https://doi. org/10.2307/j.ctvddzw1n.10.

\section{APPENDIX}

TABLE 1.

Correspondence between Ministries and Parliamentary committees by policy topic

\begin{tabular}{|c|c|c|}
\hline Topic & Ministry & Parliamentary Committee \\
\hline Agriculture & $\begin{array}{l}\text { Agricultura, Pesca y } \\
\text { Alimentación }\end{array}$ & Agricultura, Pesca y Alimentación \\
\hline \multirow{4}{*}{$\begin{array}{l}\text { Cime and } \\
\text { Justice }\end{array}$} & \multirow[t]{2}{*}{ Interior } & $\begin{array}{l}\text { Seguimiento y evaluación Acuerdos del Pacto de } \\
\text { Estado en materia de Violencia de Género }\end{array}$ \\
\hline & & Interior \\
\hline & \multirow[b]{2}{*}{ Justicia } & Justicia \\
\hline & & $\begin{array}{l}\text { Investigación utilización ilegal de efectivos, medios } \\
\text { y recursos del Ministerio del Interior }\end{array}$ \\
\hline $\begin{array}{l}\text { Economy \& } \\
\text { Commerce }\end{array}$ & $\begin{array}{l}\text { Asuntos Económicos } \\
\text { y Transformación } \\
\text { Digital }\end{array}$ & Covid19 (reactivación Económica) \\
\hline \multirow[t]{2}{*}{ Education } & $\begin{array}{l}\text { Ciencia } \\
\text { e Innovación }\end{array}$ & \multirow[t]{2}{*}{ Ciencia, Innovación y Universidades } \\
\hline & Universidades & \\
\hline
\end{tabular}




\begin{tabular}{|c|c|c|}
\hline Topic & Ministry & Parliamentary Committee \\
\hline \multirow[b]{2}{*}{ Education } & \multirow{2}{*}{$\begin{array}{l}\text { Educación y } \\
\text { Formación } \\
\text { Profesional }\end{array}$} & Educación y Formación Profesional \\
\hline & & Cultura y Deporte \\
\hline \multirow[t]{2}{*}{ Environment } & $\begin{array}{l}\text { Derechos Sociales y } \\
\text { Agenda } 2030\end{array}$ & $\begin{array}{l}\text { Comisión Mixta para la Coordinación y } \\
\text { Seguimiento de la Estrategia Española para alcanzar } \\
\text { los Objetivos de Desarrollo Sostenible (ODS) }\end{array}$ \\
\hline & Transición Ecológica & Transición Ecológica y Reto Demográfico \\
\hline \multirow{5}{*}{ Foreign affairs } & \multirow{5}{*}{$\begin{array}{l}\text { Asuntos Exteriores, } \\
\text { Unión Europea y } \\
\text { Cooperación }\end{array}$} & Cooperación Internacional para el Desarrollo \\
\hline & & Comisión Mixta para la Unión Europea \\
\hline & & Covid19 (grupo de trabajo UE) \\
\hline & & $\begin{array}{l}\text { Ponencia/ consecuencias derivadas de la salida del } \\
\text { Reino Unido de la UE el 1/02/2020 y la futura } \\
\text { relación con dicho Estado }\end{array}$ \\
\hline & & Asuntos Exteriores \\
\hline \multirow[b]{2}{*}{ Government } & $\begin{array}{l}\text { Política Territorial y } \\
\text { Función Pública }\end{array}$ & Política Territorial y Función Pública \\
\hline & $\begin{array}{l}\text { Presidencia, } \\
\text { Relaciones con las } \\
\text { Cortes y Memoria } \\
\text { Democrática }\end{array}$ & $\begin{array}{l}\text { Comisión calidad democrática, contra corrupción y } \\
\text { reform. inst. y leg. }\end{array}$ \\
\hline \multirow{3}{*}{ Health } & Consumo & $\begin{array}{l}\text { Comisión Mixta para el Estudio de los Problemas } \\
\text { de las Adicciones }\end{array}$ \\
\hline & \multirow[b]{2}{*}{ Sanidad } & Sanidad y Consumo \\
\hline & & $\begin{array}{l}\text { Covid19 (grupo de trabajo Sanidad y Salud } \\
\text { pública) }\end{array}$ \\
\hline \multirow{2}{*}{ Labour } & $\begin{array}{l}\text { Inclusión, seguridad } \\
\text { Social y Migraciones }\end{array}$ & \multirow{2}{*}{$\begin{array}{l}\text { Seguimiento y Evaluación de los Acuerdos Pacto de } \\
\text { Toledo }\end{array}$} \\
\hline & $\begin{array}{l}\text { Trabajo y Economía } \\
\text { Social }\end{array}$ & \\
\hline \multirow{3}{*}{ Rights } & $\begin{array}{l}\text { Derechos Sociales y } \\
\text { Agenda } 2030\end{array}$ & $\begin{array}{l}\text { Derechos Sociales y Políticas Integrales de la } \\
\text { Discapacidad }\end{array}$ \\
\hline & & Derechos de la Infancia y Adolescencia \\
\hline & Igualdad & Igualdad \\
\hline Social policy & $\begin{array}{l}\text { Derechos Sociales y } \\
\text { Agenda } 2030\end{array}$ & Covid19 (Políticas Sociales y Sistema de Cuidados) \\
\hline
\end{tabular}




\begin{tabular}{|c|c|c|}
\hline Topic & Ministry & Parliamentary Committee \\
\hline & Interior & Comisión sobre Seguridad Vial \\
\hline Transportation & $\begin{array}{l}\text { Transportes, } \\
\text { Movilidad y Agenda } \\
\text { Urbana }\end{array}$ & Transportes, Movilidad y Agenda Urbana \\
\hline
\end{tabular}

Source: Own elaboration based on data collected by Q-Dem (www.q-dem.com)

TABLE 2.

DIFFERENCE IN MEANS OF INTEREST GROUPS' ACCESS BY POLITICAL VENUE

\begin{tabular}{lllcc}
\hline \multicolumn{1}{c}{ Interest group } & Political venues & Mean & Mean standard error & Sig. (bilateral) \\
\hline \multirow{2}{*}{ Business associations } & Government & 32,73 & 6,183 & 0,019 \\
\cline { 2 - 5 } & Parliament & 18,17 & 7,777 & \\
\hline $\begin{array}{l}\text { Citizen, ideological or } \\
\text { cause-oriented group (NGO) }\end{array}$ & Government & 18,34 & 5,259 & 0,281 \\
\cline { 2 - 5 } Companies & Parliament & 25,74 & 6,770 & \\
\hline \multirow{2}{*}{ Other } & Government & 1,99 & 1,071 & 0,926 \\
\cline { 2 - 5 } & Parliament & 2,10 & 0,778 & \\
\hline \multirow{2}{*}{ Professional associations } & Government & 12,58 & 5,602 & 0,046 \\
\cline { 2 - 5 } & Parliament & 31,66 & 6,729 & \\
\hline \multirow{2}{*}{ Unions } & Government & 20,78 & 7,489 & 0,039 \\
\cline { 2 - 5 } & Parliament & 3,07 & 1,414 & \\
\hline
\end{tabular}

\section{$\mathrm{N}: 13$ policy areas}

Source: Own elaboration based on data collected by Q-Dem (www.q-dem.com)

Presented for evaluation: June $11^{\text {th }}, 2021$.

Accepted for publication: October $15^{\text {th }}, 2021$.

\section{LAURA CHAQUÉS-BONAFONT}

laurachaques@ub.edu

Catedrática de Ciencia Política de la Universidad de Barcelona e investigadora en el Institut Barcelona d'Estudis Internacionals (IBEI). Ha sido investigadora en la New School for Social Research (Nueva York), la Universidad de Washington (Seattle) y la Universidad de North Carolina at Chapel Hill entre otras instituciones. Actualmente coordina las actividades del grupo de investigación sobre la 
Calidad de la Democracia (www.q-dem.com). Colabora en diferentes redes internacionales de investigación académica, especialmente con el Comparative Agendas Project, y ha contribuido al desarrollo de un gran número de bases de datos que sirven para cuantificar la dinámica de la agenda en perspectiva comparada. En la actualidad, su investigación se centra en el estudio de la representación política y la dinámica de la agenda y la participación de los grupos de interés en el proceso de elaboración de las políticas públicas. Ha publicado diferentes monografías, capítulos de libro y artículos académicos sobre estos temas. El resultado de sus investigaciones ha recibido el reconocimiento de diferentes instituciones como el premio ICREA academia.

\section{IVÁN MEDINA}

ivan.medina.iborra@gmail.com

Doctor europeo en Ciencia Política por la Universidad Autónoma de Barcelona y actualmente profesor contratado en la Universidad de Valencia. Ha realizado estancias de investigación en las universidades Autónoma de Madrid, NOVA de Lisboa, Edimburgo y West of England (Bristol). En solitario o coautoría ha publicado dos libros y quince capítulos en editoriales de primer nivel como Barbara Budrich, Peter Lang, Springer, Centro de Investigaciones Sociológicas, Tirant Lo Blanch y Centro de Estudios Políticos y Constitucionales. También ha publicado artículos en revistas indizadas como la Revista Española de Investigaciones Sociológicas, la Revista Española de Ciencia Politica, la Revista de Estudios Políticos y la European Urban and Regional Studies y Contemporary Politics. Ha escrito sobre la evolución de las organizaciones empresariales en España, las repercusiones del neocorporatismo para la articulación de los intereses empresariales en España, la implicación de la eliminación de la cuota cameral en las cámaras de comercio espańolas, así como la participación de las organizaciones empresariales en la gobernanza regional. 